\title{
Realities of Teachers' Professional Development in Community Campuses of Tribhuvan University
}

\author{
Nani Babu Ghimire \\ Lecturer, Siddha Jyoti College, Sindhuli \\ Email for correspondence: nanibabughimire@gmail.com
}

\begin{abstract}
Teacher professional development (TPD) is the modern aspect of teaching learning process. To do effective teaching, the teacher should be trained, excellent as well as up-date according to the change of time. The main purpose of this paper is to explore realities of the teachers' professional development of the teachers in community campuses of Tribhuvan University (TU). There is great importance of TPD in the teachers of the community campuses since it helps the teacher to develop various kinds of professional skills, knowledge, new techniques and modern technology of teaching. Similarly, there is the great role of TU for the TPD of the teachers of community campuses. As the affiliation university it should organize subject wise teachers' training time and again. Similarly, it should hold seminar, workshop and conference on the burning issues of teaching and learning. Teachers' professional development is the demand of the present time and promoting teachers' capacity is the most important aspect of the quality education. This article is based on the theme of the mini research which is approved by University Grants Commission (UGC) Nepal.
\end{abstract}

Key words: Community campus, teacher professional development, realities, policies and practices.

\section{Introduction}

Teachers are central component in the determination of the success of each and every educational program. They are responsible for the overall dynamism of the academic activities. In order to make the overall academic program dynamic they themselves need to be dynamic and active. They need to keep themselves updated and competent which is possible through their professional development. Teachers' professional development (TPD) is usually defined as an attempt designed carefully to develop the teaching skills in teachers. Tomlinson $(1995$, p. 9) has defined teaching as 'an activity designed to promote learning'. In this sense teachers' professional development is an attempt to help teachers designed to promote their learning. The term professional development is defined as producing teachers to:

- understand how and to whom they are accountable;

- be able to obtain recognize specialist qualification as a result of considerable period of study;

- $\quad$ see the value of, and have the easy access to professional journals;

- $\quad$ participate in professional debates; 
- belong to and participate in the activities of a professional body (such as reading news letter, attending conferences) and

- develop flexible, informed decision making skills.

As the points mentioned above, tell us about the professional teachers and the organized and systematic way of equipping teachers with those competencies is teachers' professional development. Professional development, as defined by the National Professional Development Council in 2000, is: "a lifelong collaborative learning process that nourishes the growth of individuals, teams, and the school through a daily job-embedded, learner-centered, focused approach" (DuFour, Eaker, \& Du Four, 2006, p. 217). Mertler (2005), however, contended that traditional professional development sessions were "a gathering of teachers, usually after a long day of teaching or on a jam-packed workshop day, who sit and listen to an expert describe a new methodology, approach, or instructional material that they typically do not believe relates directly to their classroom situations or teaching styles" (Mertler, 2005, p. 15). Mertler's (2005) description of professional development is not far from what many educators have experienced. Here in lies much of the problem. While administrators and school boards are finally beginning to focus more on professional development in schools across the nation, unfortunately, resistance from teachers is posing a serious threat to its success (Borko, 2004; Burke, 1997; Dillon, 1976; Jehlen, 2007; Torff \& Sessions, 2008; Zimmerman \& May, 2003). Smith and Gillespie (2007) conducted another study entitled 'Research on Professional Development and Teacher Change: 'Implications for Adult Basic Education' in order to find out impact of teachers professional development on student achievement. The study indicated that the research the teachers' professional development program directly increase the teachers effectiveness and it was also found that there is much to be researched in the areas to understand the relationship better.

TPD is carried out in a number of ways. Traditionally, obtaining university degree was the only way to teachers' professional development. Later, it was felt that training was essential to make the use of university education in real teaching. Recently, the researchers have found that training cannot be transformed in real sense unless create favorable context. For that, we need mentoring and peer support, connection with the professional group and regular meeting with support from the peers of similar experience and spirit. In Nepal, currently, there are nine universities, among them TU is the oldest and largest one. Being the oldest University, it has been mainly responsible for producing required manpower so far. In spite of being the biggest University in Nepal, people believe that it has not been systematic in many respects. It is claimed that TU fails to publish result in time and other curricular programs are also not very much scheduled. Teachers' professional development is not exception in the system. It is said that the TU does not have very sharp vision and policies regarding the professional development of the faculty members. Some researcher shows that the training programs under TU have really been traditional and limited to formality. They are also not very updated and not dynamic.

\section{Research Questions}

- How Tribhuvan University has been implementing modalities of teachers' professional development at community campuses?

- How teachers have been appraising such modalities from policy and practical levels. 


\section{Research Design}

The study is devoted to explore the realites of TPD in community Campuses rather than criticizing the existing teachers' professional development strategies. In so doing, I applied qualitative research approach in which the inquirer often makes knowledge claims based primarily on constructivist perceptive or advocacy/participatory paradigms or both (Creswell, 2003) p.18). Under both paradigms, I applied multiple case study methodology that investigates a contemporary phenomenon within its real-life context; when the boundaries between phenomenon and context are not clearly evident; and in which multiple sources of evidence are used (Yin, 1984, p. 23). I choosed three different TU affiliated community campuses of Sindhuli District as multiple case and then purposively selected three teachers (i.e. one form one campus) as an unit of analysis (Yin, 1984). During the study, the participants' real names have been disclosed in accordance with research ethics. The information I collected is in-depth interview based with open-ended questions.

\section{Satisfaction on Teaching Profession}

Talking about the satisfaction of the teaching profession, Teacher A said that, I am satisfied with my profession. Teaching profession is done for self satisfaction. I have got opportunity to teach in higher level and I am producing higher level manpower. I have got opportunity to provide quality education in higher level. So I am satisfied with my profession. As a researcher, these statements made me happy because the teachers who are teaching in community campuses are satisfied with their profession.

While taking about satisfaction in teaching Teacher B explained that,

I was satisfied with my profession in the past because it was one of the honored jobs, everyone would respect the teachers, there was quality in education and the teacher could do self decision. They could teach according to their plan. So I was satisfied in the past few years. But, after 4-5 years, I am not satisfied with my profession. I am frustrated from teaching profession because there is great political pressure in campus. The teachers can't teach according to their plan. Students are not doing systematic politics. They are disturbing the classes by doing a lot of political activities. The teachers cannot do any decision themselves. Teachers are not respected.

This statement appears to clarifying that some teachers of community campuses are not satisfied at present because of the unsystematic political circumstances of the country. Unnecessary political interfere by the political leaders and students is decreasing the status of teaching profession in community campuses. Teachers are not getting respect. Teacher $\mathrm{C}$ agrees with what the Teacher A said in the matter of the satisfaction of the teaching profession. From the above mentioned opinions of the participants it is assumed that the teachers in community campuses are satisfied in their professional activities, but external factors like politics by students and leaders of the political parties are disturbing them to do their academic functions.

\section{Ground Realities of Teachers' Professional Development}

In this context, Teacher A, who is also Campus Chief of a community campus, expressed that, 
Teachers' professional development is good opportunity of teachers. But I have not got any kinds of opportunity for teacher's professional development. I have not got any opportunity to attend in training, workshop and orientation programs. The teachers have not got any prize, appreciation and encouragement from concerned university. The affiliated university (TU) is passive in teachers professional Development. TU has not organized any training, workshop, seminar, orientation programs for the development of teacher's profession. In the same may, TU has not given any opportunity for the teachers' professional development to the teachers of affiliated campuses in comparison to the teachers of constituent campuses. There is discrimination between the teachers of community campuses and constituent campuses.

Opinion expressed by him showed that TPD is important aspect of the teachers of community campuses but they have not any opportunities for professional development. Similarly, Teacher B also highlighted that,

Many community campuses are in remote area of the country because of which the teachers who are teaching in these campuses haven't got a lot of opportunity to develop their teachers' professional qualities. The teachers are not using new technology to teach in the classroom in the sense that they are not familiar with the new innovation of language teaching learning process. The teachers have not got any training on new methods and techniques of teaching. So teachers are not applied these new methodology in the classroom. Teachers are very backing position in term of theirs' professional development.

From the above quote, it enlightened me that the condition of the TPD of the teachers of community campuses is very poor. They are unknown about the new methodologies of teaching. According to the development of science and technologies, many new innovations are created in the field of teaching and learning, but the teachers of community campuses are not familiar with them because of the lack of the excess in such modern development of teaching and learning. In this connection Teacher $\mathrm{C}$ mentioned that, the campuses have not any fund for research works to the teachers. In other words, teachers cannot get any fund from the campuses to do any kinds of pedagogical researches. Although, University Grants Commission and Dean Office of faculty of education (FOE) have granted some fund for the teacher for research work which is not sufficient. Teachers have not much more skill of doing research work as well. The above story is the realities of the teachers of community campuses. The community campuses have not a lot of funds to encourage the teachers to do research works. So the affiliated university and other agencies need to provide such opportunities for the teachers of the community campuses by raising the funds. From the statements expressed by all three participants it is presumed that the condition of the professional development of the teachers of the community campuses is not satisfied. The teachers have not got opportunity to take part in the training, research works, seminars and others academic works, they are only teaching, which is not the only sufficient for TPD.

\section{Participating in Professional Development Training}

Here, I made an effort to hit upon the teachers participation in professional development training. Training is one of the most important aspects of teacher's professional development. The teachers should be trained in their own subjects according to the demand of time or changes of the contents. The teachers need to be refreshed themselves time to time by taking trainings, or participating 
in seminar/workshop or writing different journal articles to develop their professions. Regarding the participation in professional development training, Teacher A expressed: I have not participated in any kind of training which is related to my own subjects. The trainings on certain subjects are not organized either by concerned Dean Office or any other agencies. I have not taken part in any other training as a Campus Chief. I have not got any opportunity to take part in any training which is related to the development of administrative skill as a Campus Chief. In this context I found that most of the teachers have not got opportunities to take part in trainings of professional development like 'teacher training' 'training for campus Chief'. The teachers are in so back that they are not up-dated in the current knowledge because they have not participated in any kinds of training that is related to TPD. In the same way, Teacher B produced the following remarks:

I have taken part in curriculum dissemination program which is organized by Dean Office of FOE. Except this, I have not taken part in any kinds of training. Neither TU nor other agencies has called us in any kind of training. So the teachers of community campuses are not trained and refreshed according to the demand of time. The above story is the mirror of the participation of the teachers in the training programs. The response of this participant showed very painful situation of the teachers of community campuses in terms of vocational training. This made me surprise how the teachers of community campuses are teaching in their campuses in such situation. Teacher $\mathrm{C}$ also supports Teacher A and B by saying she has not taken any kinds of professional training. All three participants agreed that the teachers of community campuses have not got lots of opportunity in the participation of professional training since the concerned agencies are not organizing such kinds of the trainings.

\section{Concluding Summary}

The study explored that the status of teachers' professional development in community campuses are not satisfactory. The concerned agencies are not very much responsible and active in TPD of the teachers in community campuses. The concluding summary of the study are as follows:

- Most of the teachers of community campuses are satisfied with their profession because they are producing higher level man powers for the nation. But some teachers of the community campuses are not satisfied because of the political interfere by local political leaders and the leaders of the students in the academic works of the teachers.

- The ground realities of the teachers' professional development of the teachers of community campuses in not satisfactory. Neither they have participated in training nor have they involved in any kinds of professional workshop, seminar, and conferences. They are only teaching in their own campuses. They have not any excess in internet and other new informational technologies. They are unknown about the new methodologies of teaching. They have not done much more research in the field of teaching and learning. Similarly, they have not published much more articles in journals and newspapers. Even they have not got training in their own subjects which are the painful situation of the teachers of the community campuses. The community campuses have not a lot of funds to encourage the teachers to do research works. The condition of the professional development of the teachers of the community campuses is not satisfied. The teachers have not got opportunity to take part in the training, research works, seminars and other academic works, they are only teaching in the classroom which is not the sufficient for TPD. 
- Most of the teachers have not got opportunities to take part in trainings of professional development like 'teacher training' 'training for Campus Chief'. The teachers are in so back that they are not updated in the current knowledge because they have not participated in any kinds of training that is related to TPD. This indicates that the higher level manpower is not trained, and they are teaching according to the knowledge they had acquired at the time of their study. Only UGC has provided some grants for the purpose organizing different kinds of training like 'course refresher', 'research methodology', 'teachers' training 'etc. to the community campuses which is not enough for the proper professional development of the teachers. The teachers of community campuses have not got lots of opportunity in the participation of professional training since the concerned agencies are not organizing such kinds of the trainings.

\section{Conclusion/Suggestion}

The study came up with the conclusion that there is big gap between policies and implementation of the teachers' professional development. On one hand policies are not sufficient for addressing teachers' professional development and on the other hand existing policies are not implementing qualitatively. No doubt, teachers' professional development is the demand of the present time and promoting teachers' capacity is the most important aspect of the quality education. The Teachers, Campus Chief, CMC, Dean, and other administrative personal should be collectively aware on TPD of community campuses. Finally, on the basis of discussions and conclusion, I have also made some fruitful suggestions. For the satisfaction of the profession of the teachers of the community campuses there should not be political interfere by the local political leaders and students. They should not give pressure to the teachers to the works on their own favor. The teachers should get freedom to do the work on their own interest according to the norms of academic worth. The teachers of community campuses have not got opportunity to take part in the different activities like trainings, seminars, workshops, orientation programs etc. of TPD. So the affiliated university, Dean Office and other agencies should provide such opportunities for the teachers of the community campuses by raising alternative funds. The teachers themselves must become curious enough to involve in mini/research projects for mounting professional development activities.

\section{References}

American Federation of Teachers (1995). Principles for professional development. Washington, DC: Author.

Anders, P. L., Hoffman, J. V., \& Duffy, G. G. (2000). Teaching teachers to teach reading: Paradigm Shifts, Persistent Problems, and Challenges. In M. L. Kamil, P. B. Mosenthal, P. D. Pearson \& R. Barr (Eds.), Handbook of Reading Research Volume III (pp.719-742) New Jersey: Erlbaum Associates.

Cown, R, Philips, D. \& Walters, S. (n. d.) Teaching Practice Handbook. Retrieved form http://www. scribed.com/doc/10480945/Teaching practice

Creswell, J. W. (2003). Research design: Qualitative, quantitative and mix methods approaches (2nd ed.). Thousand Oak, CA: Sage Publication.

Duffy, G. G. (2005). Developing metacognitive teachers: Visioning and the expert's changing role in teacher education and professional development. In S. E. Israel, C. C. Block, K. L. Bauserman, 
\& K. Kimnucan-Welsch (Eds.), Meta cognitive in literacy learning: Theory assessment, instruction and professional development (pp.299-314). Mahwah, NJ: Lawrence Erlbaum.

Flyvbjerg, B. (2007). Five misunderstandings about case-study research in Qualitative Research Practice: Concise. Paperback Edition. Sage, pp. 390-404

Guskey, T. (2000). Evaluating professional development. Thousand Oaks, CA: Corwin Press.

Host, M. \& Runeson, P. (2008). Guidelines for conducting and reporting case study research in software engineering. Empir Software Engineering.

Lambert, L. (2003). Leadership capacity for lasting school improvement. Alexandria, VA: Association for Supervision and Curriculum Development.

Lee, A. S. (1989) A scientific methodology for MIS case studies. MIS, 13(1), 33-54. Doi: $10.2307 / 248698$

Lindstrom, P. \& Speck, M. (2004). The principal as professional development leader. Thousand Oaks, CA: Corwin Press Practice: Concise Paperback Edition. Sage, pp. 390-404

Maldarez, A. \& Bodoczky, C. (1999) Mentor Courses A Resource Bookfor Trainer-Trainers Cambridge: Cambridge University Press.

Maldarez, A. \& Wedell, M. (2007). Teaching Teachers: processes and Practices. London: Continuam International Publishing Group.

Mertler, C. (2005). Action research: Teachers as researchers in the classroom. Minneapolis, MN: Sage Publications, Incorporated.

Morewood, A. (2007). The impact of school-wide professional development on teschers' practices: Acase study of a reading first school in Pennsylvania. University of Pittsburgh.

Sanders, W. L. \& Rivers, J. C. (1996). Cumulative and residual effects of teachers on future student academic achievement. (R11-0435-02-001-97). Knoxville, TN: University of Tennesse ValueAdded Research and Assessment Center.

Smith, M. K. (2001). 'David A. Kolb on experiential learning', the encyclopedia of informal education. Retrieved from http://www.infed.org/b-explrn.htm

Thomson, R. (2007). Seven Principles of Good Practice Teaching. Retrieved from http://www.westga. edu

Woodward, T. (2003) Loop Input. ELT Journal, 57, 301-304. Oxford: Oxford Press Retrieved from http://eltj.oxfordjournals.org/content/57/3/301.full.pdf

Yin, R. K. (1984). Case study research: Design and methods. Newbury Park, CA: Sage. 